\title{
HUBUNGAN MAGNESIUM SERUM DENGAN KADAR GLUKOSA DARAH PADA DEWASA OVERWEIGHT DAN OBESITAS
}

\section{The Association between Serum Magnesium with Blood Glucose Level of Overweight and Obese Adults}

\author{
Dina Setiawati *, AMP Nuhriawangsa, Brian Wasita
}

\begin{abstract}
ABSTRAK
Latar Belakang: Timbunan lemak pada obesitas menjadi pemicu terjadinya stress oksidatif dan inflamasi sitemik penyebab resistensi insulin sehingga risiko terjadinya diabetes mellitus akan meningkat. Magnesium merupakan kofaktor berbagai enzim dalam metabolisme glukosa yang berperan dalam proses ambilan glukosa di otot dan juga sebagai antiinflamasi. Asupan zat gizi yang baik dapat mencegah terjadinya penyakit metabolik.

Tujuan: untuk mengevaluasi hubungan magnesium serum, asupan energi, zat gizi makro dan magnesium dengan glukosa darah puasa pada dewasa overweight dan obesitas.

Metode: Penelitian crossectional terhadap 93 orang dewasa dengan status gizi lebih atau overweight (IMT $\geq 25-29,9 \mathrm{~kg} / \mathrm{m}^{2}$ ) dan obesitas (IMT $\geq 30 \mathrm{~kg} / \mathrm{m}^{2}$ ) pada bulan Februari hingga Mei 2019 di Kecamatan Serengan Kota Surakarta. Pemeriksaan magnesium serum dengan metode kalorimetri dan glukosa darah puasa dengan metode heksokinase. Penilaian asupan energi, zat gizi makro dan magnesium dengan food recall $2 \times 24$ jam. Analisis bivariat menggunakan korelasi Pearson dengan nilai $\mathrm{p}<0,05$ dilanjutkan analisis multivariabel regresi linier ganda dengan $\mathrm{Cl} 95 \%$.

Hasil: Tidak ada korelasi signifikan asupan energi, zat gizi makro dan magnesium dengan glukosa darah. Adanya korelasi negatif yang signifikan antara kadar serum magnesium dengan glukosa darah puasa pada dewasa overweight dan obesitas $(p=0,009 ; r=-0,286 ; C 195 \%=-71,321-(-10,480))$.

Kesimpulan: Kadar magnesium serum merupakan faktor yang paling berhubungan dengan glukosa darah pada orang dewasa overweight dan obesitas di Kecamatan Serengan Kota Surakarta. Glukosa darah akan meningkat seiring dengan penurunan kadar magnesium serum.
\end{abstract}

Kata kunci: magnesium serum, overweight, obesitas, glukosa darah, dan diabetes

\section{ABSTRACT}

Background: Fat deposits in obesity can trigger oxidative stress and systemic inflammation that cause insulin resistance, which increases the risk of diabetes mellitus. Magnesium is a cofactor of various enzymes in glucose metabolism that plays a role in the process of glucose uptake in the muscles and also acts as an anti-inflammatory. Good intake of nutrients can prevent the metabolic diseases.

Objectives: to evaluate the correlation among serum magnesium, energy, macro nutrient and magnesium intake with fasting blood glucose levels in overweight and obese adults.

Methods: A cross-sectional study was conducted on 93 overweight (BMI $\geq 25-29.9 \mathrm{~kg} / \mathrm{m2}$ ) and obese (BMI $\geq 30 \mathrm{~kg} / \mathrm{m2}$ ) adults in February to May 2019 in Serengan District, Surakarta City. The measurement of serum magnesium using kalorimetri and fasting blood glucose using hexokinase method. Energy, macro nutrition and magnesium intake was assessed using $2 \times 24$ hour food recall. The bivariate analysis was carried out using Pearson correlation with $p$ value of $<0.05$ followed by multivariable multiple linear regression analysis with $95 \% \mathrm{Cl}$.

Results: There was no significant correlation of energy, macro nutrient and magnesium intake with blood glucose level. There was a significant negative correlation between serum magnesium and fasting blood glucose in overweight and obese adults ( $p=0.009 ; r=-0.286 ; C 195 \%=-71.321-(-10.480)$ ).

Conclusions: Serum magnesium are the factors most associated with blood glucose in overweight and obese adults. Blood glucose will increase along with decreasing level of serum magnesium.

Keyword: serum magnesium, overweight, obesity, blood glucose, and diabetes

\author{
*Koresponden: \\ dinasetiawati20@yahoo.co.id \\ Universitas Sebelas Maret, Surakarta, Jawa Tengah, Indonesia
}




\section{PENDAHULUAN}

Permasalahan gizi di Indonesia tidak lagi didominasi oleh masalah gizi kurang tetapi juga gizi lebih. Riset Kesehatan Dasar (RISKESDAS) tahun 2018 mencatat prevalensi obesitas orang dewasa sebesar $21,8 \%$, artinya terjadi peningkatan sebesar $7 \%$ dibanding tahun 2013. ${ }^{1}$ Dinas Kesehatan Kota Surakarta mencatat prevalensi obesitas berdasarkan hasil penilaian status gizi terhadap pasien yang berkunjung ke puskesmas. Dari 17 puskesmas yang tersebar di lima kecamatan tercatat bahwa Kecamatan Serengan memiliki prevalensi obesitas tertinggi yaitu $27,12 \%$. Kejadian obesitas berhubungan dengan berbagai faktor seperti usia, jenis kelamin, keturunan, aktifitas fisik dan juga asupan makan. ${ }^{2}$ Faktor utama yang menyebabkan kegemukan dan obesitas adalah kebiasaan makan, genetik, lingkungan, metabolisme dan gaya hidup. ${ }^{3}$

Kegemukan dan obesitas dapat didefinisikan sebagai kelebihan lemak tubuh yang dapat menjadi faktor risiko gangguan metabolik diantaranya hipertensi, intoleransi glukosa, dislipidemia dan pro inflamasi. ${ }^{5}$ Obesitas merupakan faktor risiko terjadinya penyakit diabetes mellitus, meskipun faktor ini dapat dimodifikasi dengan perubahan gaya hidup. Prevalensi penyakit diabetes meningkat seiring dengan peningkatan angka obesitas. Sebesar $14,8 \%$ orang dewasa (> 18 tahun) obesitas berisiko menderita penyakit diabetes mellitus. ${ }^{6}$ Peningkatan jaringan adiposit pada obesitas berkaitan juga dengan terjadinya penyakit diabetes mellitus tipe 2.7 Adiposit menghasilkan sitokin proinflamasi seperti Interleukin 1 (IL-1) dan Tumor Necrosis Factor (TNF) serta menstimulasi produksi radikal bebas seperti Reactive Oxygen Species (ROS) yang berperan menyebabkan resistensi insulin. ${ }^{8}$ Ketidakseimbangan energi ekspenditur dan asupan makan secara kronis juga merupakan faktor risiko terjadinya obesitas. ${ }^{9}$ Tingginya konsumsi pangan sumber karbohidrat dan olahannya pada masyarakat Indonesia berhubungan kuat dengan peningkatan risiko obesitas. ${ }^{10}$ Kebiasaan atau pola makan tinggi karbohidrat, lemak, protein dan kolesterol berkaitan dengan gangguan intoleransi glukosa, sebaliknya pola makan tinggi serat dan vitamin memiliki efek yang positif terhadap sensitivitas insulin dan toleransi glukosa. ${ }^{11}$ Makanan orang Asia didominasi oleh kelompok serealia yang merupakan sumber karbohidrat menyebabkan penurunan konsumsi protein dan susu serta berkaitan dengan risiko penyakit metabolik. ${ }^{12}$ Diet tinggi karbohidrat, lemak, dan protein berkaitan dengan gangguan toleransi glukosa. ${ }^{11}$ Overnutrisi kronik akan memicu inflamasi sistemik grade rendah dan gangguan metabolik yang menyebabkan resistensi insulin. ${ }^{13}$

Sebuah studi menunjukkan bahwa derajat obesitas berhubungan juga dengan rendahnya konsentrasi magnesium (Mg) serum. ${ }^{14}$ Penelitian lain pada anak dan remaja menyebutkan bahwa kadar $\mathrm{Mg}$ serum pada obesitas cenderung lebih rendah dibandingkan dengan yang memiliki berat badan normal. ${ }^{15} 16 \mathrm{Mg}$ serum berkaitan dengan sindroma metabolik, diabetes mellitus dan obesitas abdominal. Pada orang dengan sindroma metabolik ditemukan adanya hubungan level hipomagnesemia berat $(\leq 1,2$ $\mathrm{mg} / \mathrm{dl}$ ) dengan peningkatan biomarker infalamasi seperti TNF- $\alpha$ dan C-reactive Protein (CRP). ${ }^{17}$ Hipomagnesemia $<1,7 \mathrm{mg} / \mathrm{dl}$ ) pada orang obesitas dapat meningkatkan terjadinya stress oksidatif yang menyebabkan penurunan sekresi insulin. ${ }^{8}$ Total magnesium serum merupakan pemeriksaan yang dapat menunjukkan status magnesium dalam tubuh. ${ }^{18}$ Magnesium serum merupakan indikator yang spesifik meskipun kurang sensitif dalam menentukan defisiensi magnesium dalam tubuh. ${ }^{19}$ Studi review menunjukkan bahwa pemeriksaan magnesium serum dapat digunakan sebagai biomarker untuk menentukan status magnesium. ${ }^{20}$ Selain itu pemeriksaan magnesium serum lebih banyak digunakan untuk menentukan status magnesium dalam tubuh dibandingkan dengan pengukuran magnesium pada urin, tinja atau jaringan lainnya dan dianggap reliabel untuk mewakili simpanan magnesium dalam tubuh. ${ }^{21}$

Sampai saat ini pengukuran magnesium serum banyak dilakukan pada pasien Diabetes. Peneliti tertarik untuk menganalisis hubungan kadar magnesium bersama dengan variabel asupan energi dan zat gizi makro serta magnesium terhadap kadar glukosa darah puasa pada dewasa overweight dan obesitas di Kecamatan Serengan Kota Surakarta. Penelitian ini dilakukan untuk mengevaluasi seberapa besar hubungan kadar magnesium yang merupakan salah satu penilaian status zat gizi mikro terhadap kejadian hiperglikemia pada orang dewasa overweight dan obesitas tanpa penyakit penyerta. Penelitian ini diharapkan memberikan informasi tentang kaitan kadar magnesium serum, asupan energi, zat gizi makro dan magnesium dengan kejadian diabetes khususnya pada orang dewasa overweight dan obesitas.

\section{METODE}

Penelitian observasional menggunakan desain cross sectional yang dilaksanakan bulan Februari hingga Mei 2019. Pemilihan lokasi penelitian berdasarkan data prevalensi obesitas Dinas Kesehatan Kota Surakarta, dan terpilih Kecamatan Serengan dengan prevalensi obesitas sebesar $27 \%$. Populasi dalam penelitian ini adalah orang dewasa dengan status gizi lebih atau overweight (IMT $\geq$ $25-29,9 \mathrm{~kg} / \mathrm{m}^{2}$ ) dan obesitas (IMT $\geq 30 \mathrm{~kg} / \mathrm{m}^{2}$ ) yang merupakan peserta Pos Pembinaan Terpadu Penyakit Tidak Menular (POSBINDU PTM) di empat kelurahan di Kecamatan Serengan Kota Surakarta. Besar sampel didapat dari hasil perhitungan rumus Lameshow yaitu mengestimasi proporsi pada populasi terbatas dengan tingkat keyakinan 95\%. Pengambilan sampel dengan cara total sampling sehingga didapat 93 orang dewasa dengan rentang usia 20-57 tahun dan memenuhi kriteria inklusi yaitu, IMT $\geq 25 \mathrm{~kg} / \mathrm{m}^{2}$, tidak dalam kondisi hamil, belum terdiagnosa penyakit degeneratif seperti diabetes mellitus, kardiovaskuler, dan gagal ginjal dibuktikan dari 
catatan riwayat pemeriksaan kesehatan di puskesmas dan POSBINDU PTM. Subyek yang berpartisipasi dalam penelitian telah menandatangani lembar persetujuan atau informed consent. Persetujuan etik diperoleh dari Komite Etik Penelitian Kesehatan Fakultas Kedokteran Universitas Sebelas Maret Surakarta dengan nomor 426/UN27.6/KEPK/2019.

Data primer didapatkan dari hasil pengukuran antropometri antara lain berat badan dengan timbangan digital merk Tanita BC 541, tinggi badan dengan microtoice merk OneMed ketelitian $0.1 \mathrm{~cm}$. Penentuan Indeks Massa Tubuh (IMT) dengan pembagian berat badan $(\mathrm{kg})$ menurut tinggi badan $\left(\mathrm{m}^{2}\right)$. Data aktifitas fisik didapatkan dari hasil wawancara menggunakan International Physical Activity Questionnaire (IPAQ) dan dinyatakan dalam met.menit/minggu. Penilaian asupan energi dan juga zat gizi dari rata-rata food recall $2 \times 24$ jam. Kategori asupan energi dan zat gizi dikatakan lebih jika $\geq 120 \%$ Angka Kecukupan Gizi (AKG), baik 80-120\% AKG dan kurang jika $<80 \%$ AKG.

Pemeriksaan terhadap serum magnesium menggunakan metode kalorimetri $\begin{array}{lll}15 & 17 & 22 \\ \text { dan glukosa }\end{array}$ darah puasa dengan metode hexokinase. ${ }^{23} 24$ Pengambilan darah dilakukan pada kegiatan POSBINDU PTM di tiap-tiap kelurahan oleh petugas analis dari Laboratorium Klinik Prodia. Serum diambil pada bagian vena dan sebelumya responden diminta untuk berpuasa minimal 8 jam sebelum pengambilan darah. ${ }^{16} 2325$ Cut off points serum magnesium dikatakan normal adalah $\geq 1,7 \mathrm{mg} / \mathrm{dl} .{ }^{8} 18262721$ dan kategori kadar glukosa darah puasa adalah normal jika $<100 \mathrm{mg} / \mathrm{dl}$, prediabetes antara $100-125 \mathrm{mg} / \mathrm{dl}$, dan diabetes jika $\geq 125 \mathrm{mg} / \mathrm{dl}^{2}{ }^{28}$ Data yang dikumpulkan dikategorikan dan dianalisis menggunakan software IBM SPSS Statistic versi 23. Analisis bivariat antara variabel bebas dan terikat menggunakan uji korelasi Pearson dan dinyatakan signifikan bila nilai $p<0,05$. Analisis multivariabel regresi linier ganda untuk menguji hubungan beberapa variabel independen secara bersamaan terhadap variabel dependen dengan nilai Confidence Interval (Cl) 95\%.

\section{HASIL DAN PEMBAHASAN}

Tabel 1 menunjukkan distribusi frekuensi subjek berdasarkan jenis kelamin, usia, pekerjaan, status gizi, kategori kadar glukosa darah dan asupan zat gizi. Sebesar $87 \%$ subjek adalah wanita, sedangkan laki-laki hanya $23 \%$. Lebih dari $78 \%$ subjek berusia diatas 40 tahun dan rata-rata berpendidikan setingkat Sekolah Menengah Atas. Semakin bertambah usia maka risiko terjadinya obesitas khususnya obesitas sentral semakin tinggi. ${ }^{29}$ Hasil penelitian ini juga menunjukkan bahwa wanita dan masyarakat diatas usia 40 tahun lebih berperan aktif dalam kegiatan POSBINDU PTM yang dilaksanakan secara rutin sebulan sekali di tiap kelurahan di wilayah Kecamatan Serengan Kota Surakarta. Sebagian besar subjek adalah ibu rumah tangga, dan lebih dari 85\% diantaranya memiliki aktifitas fisik yang rendah. Aktifitas fisik pada obesitas khususnya wanita cenderung lebih rendah dibandingkan dengan non obesitas. ${ }^{30}$ Selain karena asupan makanan dan minuman yang tidak sehat sehingga menyebabkan kelebihan energi, kurangnya aktifitas dan latihan fisik dan faktor genetik juga merupakan penyebab obesitas. ${ }^{31}$ Dari 93 responden, $44 \%$ memiliki status gizi overweight dan $56 \%$ obesitas.

Tabel 1. Distribusi Karakteristik pada Dewasa Overweight dan Obesitas di Kecamatan Serengan Kota Surakarta

\begin{tabular}{lcc}
\hline Karakteristik & $\begin{array}{c}\text { Jumlah } \\
\text { (n=93) }\end{array}$ & $\begin{array}{c}\text { Persentase } \\
\text { (\%) }\end{array}$ \\
\hline Jenis Kelamin & & \\
$\quad$ Pria & 12 & 13 \\
$\quad$ Wanita & 81 & 87 \\
Usia (tahun) & & \\
20-29 & 2 & 2,1 \\
30-39 & 18 & 19,4 \\
$\quad 40-49$ & 43 & 46,2 \\
50-59 & 30 & 32,3 \\
Pekerjaan & & \\
$\quad$ Tidak bekerja/lbu Rumah Tangga & 65 & 69,9 \\
$\quad$ Buruh & 3 & 3,2 \\
$\quad$ Wiraswasta & 19 & 20,4 \\
$\quad$ Pegawai Negeri & 6 & 6,5 \\
Indeks Massa Tubuh (kg/m ${ }^{2)}$ & & \\
$\quad$ Overweight (25-29,9) & 41 & 44 \\
$\quad$ Obesitas ( $\geq 30)$ & 52 & 56 \\
Aktifitas Fisik (met.menit/minggu) & & \\
$\quad$ Rendah (<600) & 73 & 78,5 \\
$\quad$ Sedang (600-1500) & 16 & 17,2 \\
$\quad$ Tinggi (>1500) & 4 & 4,3 \\
Kadar Magnesium Serum (mg/dl) & & \\
$\quad$ Kuartil 1 (1,71-1,93) & 21 & 22,6 \\
$\quad$ Kuartil 2 (1,94-2,05) & 24 & 25,8 \\
$\quad$ Kuartil 3 (2,06-2,13) & 24 & 25,8 \\
$\quad$ Kuartil 4 (2,14-2,37) & 24 & 25,8 \\
Kadar Glukosa Darah Puasa (mg/dl) & & \\
$\quad$ Normal (<100) & 72 & 77,4 \\
$\quad$ Hiperglikemia ( $\geq 100)$ & 21 & 22,6 \\
\hline
\end{tabular}

Asupan energi, karbohidrat, protein, lemak dan serat yang rendah dijumpai pada sebagian besar subjek (Tabel 2). Asupan energi pada subjek memiliki rata-rata sebesar $1423,5 \pm 76,2 \mathrm{kkal}$; protein $40,4 \pm 13,3$ gram; lemak 47,9 $\pm 21,7$ gram; karbohidrat $208,8 \pm 65,6$ gram; serat sebesar $8,8 \pm 4,4$ gram; dan magnesium $188,4 \pm 75,8$ mg sehari. Tabel 2 juga menunjukkan rata-rata IMT sebesar $31,14 \pm 3,78 \mathrm{~kg} / \mathrm{m}^{2}$, yang artinya sebagian besar berstatus gizi obesitas. Seluruh subjek memiliki kadar magnesium serum dalam batas normal ( $\geq 1,7 \mathrm{mg} / \mathrm{dl}$ ) dengan nilai rerata $2,04 \pm 0,14 \mathrm{mg} / \mathrm{dl}$. Nilai rerata kadar glukosa darah puasa pada subjek $94,9 \pm 19,5 \mathrm{mg} / \mathrm{dl}$, dimana $77,4 \%$ subjek dengan kadar glukosa darah puasa normal dan 22,6\% mengalami hiperglikemia atau glukosa darah puasa $>100 \mathrm{mg} / \mathrm{dl}$. Peningkatan kadar 
Tabel 2. Rerata Beberapa Variabel pada Dewasa Overweight dan Obesitas di Kecamatan Serengan Kota Surakarta

\begin{tabular}{lccc}
\hline Variabel & Mean \pm SD & Minimum & Maksimum \\
\hline Usia (tahun) & $45 \pm 7$ & 25 & 57 \\
Indeks Massa Tubuh $\left(\mathrm{kg} / \mathrm{m}^{2}\right)$ & $31,14 \pm 3,78$ & 25,2 & 40,7 \\
Kadar Magnesium Serum (mg/dl) & $2,04 \pm 0,14$ & 1,71 & 2,37 \\
Kadar Glukosa Darah (mg/dl) & $94,9 \pm 19,5$ & 70 & 177 \\
Asupan Energi (kkal) & $1423,5 \pm 376,2$ & 649 & 2294,6 \\
Asupan Protein (gram) & $40,4 \pm 13,3$ & 13,4 & 67,8 \\
Asupan Lemak (gram) & $47,9 \pm 21,7$ & 1,2 & 85,2 \\
Asupan Karbohidrat (gram) & $208,8 \pm 65,6$ & 96,6 & 414,1 \\
Asupan Serat (gram) & $8,8 \pm 4,4$ & 1,6 & 24,5 \\
Asupan Magnesium (mg) & $188,4 \pm 75,8$ & 48,4 & 330,1 \\
\hline
\end{tabular}

Tabel 3 menunjukkan adanya korelasi positif yang signifikan antara asupan energi $(p=0,005 ; r=0,290)$ dan lemak ( $p=0,003 ; r=0,306)$ dengan kadar magnesium serum. Makanan sebagai sumber energi yang mengandung karbohidrat dan lemak rantai sedang akan membantu penyerapan magnesium di usus dan juga dapat meningkatkan kebutuhan magnesium karena magnesium penting dalam proses pemecahan glukosa dan pelepasan insulin. ${ }^{32}$ Tabel 3 juga menunjukkan bahwa asupan magnesium berkorelasi signifikan dengan kadar magnesium serum $(p=0,034 ; r=0,220)$. Hal ini sejalan dengan penelitian sebelumnya yang menyebutkan bahwa peningkatan kadar magnesium serum seiring dengan peningkatan asupan magnesium. ${ }^{33}$ Asupan serat juga berkorelasi signifikan dengan kadar magnesium ( $p=0,045 ; r=0,209)$. Hal ini dapat dikarenakan bahan makanan sumber serat seperti sayuran dan biji-bijian utuh merupakan sumber magnesium yang tinggi, sehingga peningkatan asupan serat berhubungan dengan peningkatan kadar magnesium. ${ }^{21}$ Magnesium merupakan mineral yang berperan sebagai antioksidan dan kofaktor beberapa enzim yang dapat menjaga stabilitas membran dan mecegah stres oksidatif. ${ }^{8}$ Fungsi ginjal merupakan kunci dalam keseimbangan magnesium dalam tubuh. Selain itu kadar magnesium juga dipengaruhi oleh asupan makanan, mobilisasi magnesium dari tulang dan otot, pengaruh berbagai hormon (paratiroid,kalsitonin dan glukagon) serta penggunaan obat-obatan seperti obat diuretik dan kemoterapi yang dapat menyebabkan ekskresi magnesium yang tidak normal. ${ }^{21}$ Hipomagnesmia dapat menyebabkan nafsu makan menurun, mual, muntah, kelelahan dan lemah. Pada kondisi hipomagnesmia berat dapat terjadi mati rasa, kesemutan, kontraksi otot, kram, kejang dan detak jantung abnormal. Sedangkan hipermagnesmia yang berat dapat menyebabkan disfungsi neuromuskular mulai dari rasa kantuk hingga depresi pernafasan, hipotonia, arefleksia dan juga koma pada kasus yang parah. ${ }^{34}$

Tabel 3. Hubungan Asupan Energi, Zat Gizi Makro dan Magnesium dengan Kadar Magnesium Serum pada Dewasa Overweight dan Obesitas di Kecamatan Serengan Kota Surakarta

\begin{tabular}{lcc}
\hline & \multicolumn{2}{c}{ Kadar Magnesium Serum } \\
\cline { 2 - 3 } & Koefisien Korelasi (r) & $\mathbf{P}$ \\
\hline Asupan Energi & 0,290 & 0,005 \\
Asupan Protein & 0,142 & 0.173 \\
Asupan Lemak & 0,306 & 0,003 \\
Asupan Karbohidrat & 0,173 & 0,097 \\
Asupan Serat & 0,209 & 0,045 \\
Asupan Magnesium & 0,220 & 0,034 \\
\hline
\end{tabular}

Keterangan: korelasi signifikan jika nilai $\mathrm{p}<0,05$; dianalisis dengan Uji Korelasi Pearson

Hasil analisis bivariat antara variabel kadar magnesium serum, asupan energi, zat gizi makro serta magnesium dengan kadar glukosa darah puasa pada Tabel 4 menunjukkan bahwa kadar magnesium serum berkorelasi signifikan dengan kadar glukosa darah puasa pada dewasa overweight dan obesitas $(p=0,002 ; r=-$ 0,320 ). Tabel 4 juga menunjukkan tidak adanya korelasi yang signifikan antara intake energi, karbohidrat, protein, dan lemak terhadap glukosa darah puasa pada orang dewasa overweight dan obesitas. Ini bisa disebabkan karena asupan energi dan zat gizi makro pada sebagian besar subjek penelitian termasuk kategori kurang. Sejalan dengan penelitian sebelumnya yang menunjukkan sebagian besar asupan energi dan zat gizi makro pada overweight dan obesitas termasuk kategori cukup dan kurang. ${ }^{29} 35$ Data asupan energi dan zat gizi dalam penelitian ini didapatkan dari rata-rata recall saat dilakukan penelitian, seharusnya perlu adanya penilaian asupan dengan semi quantitative food frequency questionnaire (SQ-FFQ) sehingga bisa lebih 
menggambarkan pola makan yang sebenarnya. Sebuah studi menyatakan bahwa metode SQ-FFQ dapat digunakan untuk menilai kebiasaan makan dan asupan zat gizi di masyarakat. ${ }^{36}$ Selain recall 24 jam dan SQ-FFQ, penilaian asupan zat gizi makro juga bisa menggunakan metode food record dimana responden mencatat semua makanan yang dikonsumsi sehingga asupan zat gizi dalam sehari dapat diketahui. ${ }^{37}$ Penelitian sebelumnya juga menunjukkan tidak adanya hubungan asupan energi dan zat gizi makro dengan kadar glukosa darah puasa pada wanita obesitas. ${ }^{38} \mathrm{Hal}$ ini dapat disebabkan oleh rendahnya rata-rata asupan energi dan zat gizi pada subjek overweight dan obesitas dalam penelitian ini. Glukosa yang dihasilkan dari metabolisme zat gizi digunakan untuk memenuhi kebutuhan energi sel atau organ tubuh seperti otak dan sel darah merah, sehingga penumpukan kelebihan glukosa yang akan diubah menjadi trigliserida untuk disimpan di jaringan lemak tidak terjadi. ${ }^{39}$ Hiperglikemia pada obesitas dapat terjadi karena penumpukan asam lemak bebas yang mendorong produksi sitokin proinflamasi sehingga memicu disfungsi endotel dan signal insulin yang berakibat pada terjadinya resistensi insulin dan menyebabkan hiperglikemia. ${ }^{40} 4113$

Analisis bivariat pada Tabel 4 memperlihatkan tidak adanya korelasi signifikan antara asupan serat dan kadar glukosa darah puasa $(p=0,245 ; r=-0,122)$. Hal ini bisa disebabkan karena rata-rata asupan serat pada subjek penelitian ini rendah, sedangkan penelitian sebelumnya menyatakan bahwa konsumsi bahan makanan sumber serat dalam jumlah yang cukup berhubungan dengan penurunan risiko sindroma metabolik. ${ }^{36}$ Selain itu penelitian lain menunjukkan bahwa asupan serat berhubungan dengan penurunan resistensi insulin pada wanita yang memiliki tingkat asupan serat yang tinggi. ${ }^{42}$

Tabel 4. Hubungan Kadar Magnesium, Asupan Energi, Zat Gizi Makro dan Magnesium dengan Kadar Glukosa Darah Puasa pada Dewasa Overweight dan Obesitas di Kecamatan Serengan Kota Surakarta

\begin{tabular}{lcc}
\hline \multirow{2}{*}{ Variabel } & \multicolumn{2}{c}{ Kadar Glukosa Darah Puasa } \\
\cline { 2 - 3 } & Koefisien Korelasi $(\mathbf{r})$ & $\mathbf{P}$ \\
\hline Kadar Magnesium Serum (mg/dl) & $-0,320$ & 0,002 \\
Asupan Energi & $-0,107$ & 0,308 \\
Asupan Protein & 0,001 & 0,993 \\
Asupan Lemak & $-0,160$ & 0,126 \\
Asupan Karbohidrat & $-0,046$ & 0,660 \\
Asupan Serat & $-0,122$ & 0,245 \\
Asupan Magnesium & 0,027 & 0,795 \\
\hline
\end{tabular}

Keterangan: korelasi signifikan jika nilai $\mathrm{p}<0,05$; dianalisis dengan Uji Korelasi Pearso

Tabel 5. Analasis Multivariat antara Kadar Magnesium dan Zat Gizi Makro dengan Kadar Glukosa Darah pada Dewasa Overwight dan Obesitas di Kecamatan Serengan Kota Surakarta

\begin{tabular}{lccccc}
\hline \multirow{2}{*}{ Variabel } & \multicolumn{2}{c}{ Kadar Glukosa Darah Puasa $(\mathbf{m g} / \mathrm{dl})$} & \multicolumn{2}{c}{ Cl 95\% } & \multicolumn{2}{c}{ Koefisien Determinasi } \\
\cline { 2 - 5 } & Koefisien & $\mathbf{p}$ & Lower & Upper & (\%) \\
\hline Kadar Magnesium Serum & $-0,286$ & 0,009 & $-71,321$ & $-10,480$ & 11,1 \\
Asupan Lemak & $-0,075$ & 0,478 & $-0,254$ & 0,120 & \\
Asupan Serat & $-0,055$ & 0,591 & $-1,124$ & 0,644 & \\
\hline
\end{tabular}

Keterangan: analisis multirariat menggunakan regresi linier ganda dengan $\mathrm{Cl} 95 \%$

Hasil analisis bivariat pada Tabel 4 menunjukkan adanya korelasi beberapa variabel independen dengan variabel dependen, sehingga dilanjutkan dengan analisis multivariabel regresi linier ganda. Variabel yang bisa masuk dalam analisis multivariabel adalah yang memiliki nilai $p<0,25$. Berdasarkan analisis bivariat pada Tabel 4 , variabel yang dapat dilanjutkan ke dalam analisis multivariat adalah kadar magnesium serum, asupan lemak dan asupan serat.

Hasil analisis akhir model regresi pada Tabel 5 menunjukkan bahwa kadar magnesium serum ( $p=0,009$; $r=-0,286 ; C \mid 95 \%=-71,321-(-10,480))$ merupakan variabel yang secara signifikan paling berpengaruh terhadap glukosa darah puasa pada dewasa overweight dan obesitas. Koefisien determinan sebesar 11,1 artinya bahwa faktor magnesium serum, asupan lemak dan serat secara bersama-sama dapat mempengaruhi kadar glukosa darah pada dewasa overweight dan obesitas sebesar 11,1\%. Penelitian sebelumnya juga menyebutkan tidak adanya hubungan asupan lemak, serat dengan kadar glukosa darah namun asupan karbohidrat merupakan faktor yang paling berpengaruh terhadap kadar glukosa darah puasa. ${ }^{43}$ Asupan karbohidrat $70-75 \%$ dari total energi dapat meningkatkan glukosa darah puasa, disamping itu diet tinggi karbohidrat juga dapat menurunkan proporsi konsumsi sumber protein seperti ikan, telur, daging dan kacang-kacangan. Gangguan toleransi glukosa berkaitan dengan diet tinggi karbohidrat, protein dan lemak. ${ }^{11}$ Pada orang obesitas yang berisiko mengalami resistensi insulin diet rendah karbohidrat dapat diterapkan, karena dengan asupan karbohidrat yang rendah maka insulin yang dibutuhkan untuk metabolisme juga menurun. ${ }^{44}$ Sebaliknya, beberapa studi menunjukkan bahwa sayur, buah dan kacang-kacangan yang mengandung serat dan indeks glikemik yang rendah dapat menjaga homeostasis 
glukosa, menurunkan konsentrasi insulin postpandrial dan memperbaiki sensitifitas insulin. ${ }^{45}$ Proses pencernaan dan penyerapan serat khususnya serat larut air yang lambat di dalam lambung dapat memperlambat pelepasan glukosa dan produksi insulin. ${ }^{46}$

Hasil penelitian ini menunjukkan tidak terjadinya hipomagnesemia pada orang dewasa overweight dan obesitas ditandai dengan kadar magnesium serum pada subjek penelitian antara 1,71-2,37 mg/dl (Tabel 1) dengan rata-rata $2,04 \mathrm{mg} / \mathrm{dl}$ (Tabel 2). Hasil ini sejalan dengan penelitian Rotter et al dan Hassan et al yang menyebutkan magnesium serum pada obesitas dalam batas normal meskipun rata-ratanya lebih rendah dari non obesitas yaitu $2,08 \mathrm{mg} / \mathrm{dl} .{ }^{47}{ }^{48}$, serta penelitian Chaudary et al yang menunjukkan rata-rata kadar magnesium pada remaja overweight antara 1,73-2,25 $\mathrm{mg} / \mathrm{dl}^{15}$ Berbeda dengan penelitian lain yang menemukan adanya hipomagnesemia pada anak dan remaja obesitas dengan rata-rata kadar magnesium 1,5 $\mathrm{mg} / \mathrm{dl}^{22}{ }^{14}$ Korelasi negatif kadar magnesium dengan glukosa darah puasa menunjukkan bahwa semakin rendah kadar magnesium serum maka semakin tinggi pula kadar glukosa darah puasa. Sejalan dengan penelitian yang menyebutkan bahwa kadar magnesium yang rendah (hipomagnesemia) tidak berhubungan dengan status obesitas, namun berkaitan dengan hiperglikemia. ${ }^{17}$ Hasil ini juga sejalan dengan penelitian lain yang menyebutkan bahwa semakin rendah kadar magnesium maka risiko penyakit DM semakin meningkat. 818

Obesitas merupakan faktor risiko penyebab diabetes tipe 2 dan juga berdampak terhadap kadar magnesium melalui gangguan metabolisme karbohidrat dan aktifitas insulin. ${ }^{18}$ Pada kondisi obesitas, sensitifitas insulin di jaringan target menurun yang disebut resitensi insulin. ${ }^{49}$ Resistensi insulin menyebabkan hati gagal menekan glukoneogenesis dan glikogenolisis, sementara sintesis asam lemak tetap berlanjut. Terjadinya resistensi insulin menyebabkan penurunan transport glukosa dan sintesis glikogen pada otot skeletal sehingga kadar glukosa darah meningkat. ${ }^{40} 50$ Magnesium (Mg) merupakan salah satu mikro nutrien yang ikut berperan dalam mengatur jalur GLUT-4 sehingga meningkatkan ambilan glukosa di otot. Mg juga memiliki kemampuan meningkatkan sensitifitas insulin melalui pengaturan jalur signal insulin dan meningkatkan afinitas reseptor insulin tyrosin kinase for ATP. ${ }^{8}$ Insulin merupakan hormon yang disekeresi oleh sel beta pankreas yang bekerja di hati, otot dan jaringan lemak untuk menyimpan energi dan menjaga keseimbangan kadar glukosa. ${ }^{51}$ Insulin mendorong perpindahan Glucose Transporter 4 (GLUT 4) dari vesikel ke membran plasma sehingga meningkatkan pengangkutan glukosa ke otot dan jaringan lemak agar konsentrasi glukosa dalam darah tetap terkendali. ${ }^{52}$

Kelebihan dalam penelitian ini adalah dilakukan pengukuran magnesium pada dewasa dengan status gizi overweight dan obesitas tanpa penyakit penyerta untuk melihat keterkaitannya dengan risiko hiperglikemia, dimana penelitian sebelumnya lebih banyak dilakukan pada pasien diabetes. Keterbatasan dari penelitian ini adalah pemeriksaan magnesium serum bukanlah gold standar dalam menentukan defisiensi magnesium meskipun beberapa penelitian terdahulu menyatakan bahwa magnesium serum dapat menggambarkan status magnesium dalam tubuh. Selain itu penelitian ini belum bisa menunjukkan apakah usia dan kadar magnesium serum merupakan faktor resiko terjadinya diabetes, karena merupakan studi crossectional yang hanya menghubungkan antar variabel. Data asupan makan hanya didapatkan dari rata-rata recall $2 \times 24$ jam, seharusnya perlu dilakukan juga penilaian dengan semi quantitative food frequency questionnaire (SQ-FFQ) sehingga bisa menggambarkan pola makan dan dapat mengukur konsumsi pangan dalam durasi harian, mingguan, bulanan atau tahunan pada subjek penelitian. Selain itu metode SQ-FFQ juga dapat digunakan untuk menilai frekuensi atau kekerapan suatu bahan makanan dikonsumsi sebagai faktor risiko permasalahan gizi. ${ }^{37}$ Perlu adanya studi untuk mempelajari faktor-faktor yang berpengaruh terhadap kadar magnesium serum termasuk pola makan zat gizi makro khususnya pada overweight dan obesitas.

\section{KESIMPULAN}

Kadar magnesium serum dalam kategori normal $(\geq 1,7 \mathrm{mg} / \mathrm{dl}) \quad$ menunjukkan tidak terjadinya hipomagnesemia pada orang dewasa overweight dan obesitas. Adanya korelasi negatif yang signifikan antara kadar magnesium serum dengan kadar glukosa darah puasa menunjukkan bahwa kadar magnesium serum yang rendah merupakan faktor yang berkaitan dengan peningkatan glukosa darah pada dewasa overweight dan obesitas.

\section{ACKNOWLEDGMENT}

Peneliti mengucapkan terimakasih kepada Pemerintah Daerah Kota Surakarta, Badan Perencanan Penelitian dan Pengembangan Daerah Kota Surakarta, Dinas Kesehatan Kota Surakarta, Kepala Puskesmas Keratonan dan Kepala Puskesmas Jayengan berserta jajarannya, Kader POSBINDU PTM di Kecamatan Serengan, Laboratorium Klinik Prodia, Dr. Ir. Adi Magna Patriadi Nuhriawangsa, S.Pt, MP, IPM dan dr.Brian Wasita, Sp.PA, Ph.D sebagai pembimbing yang memberikan bantuan pemikiran konsep dan masukan serta seluruh pihak yang telah membatu penelitian ini.

\section{REFERENSI}

1. Kemenkes RI. Hasil Utama Riskesdas 2018. Kementerian Kesehatan RI (2018).

2. Nadimin, Ayumar, Fajarwati. Obesitas Pada Orang Dewasa Anggota Keluarga Miskin Di Kecamatan Lembang Kabupaten Pinrang. Jurnal MKMI, 9-15 (2015). 
3. Chen, F. et al. Association between Childhood Obesity and Metabolic Syndrome: Evidence from a Large Sample of Chinese Children and Adolescents. 7, 1-7 (2012).

4. Xu, S and Xue, Y. Pediatric obesity: Causes, Symptoms, Prevention and Treatment ( Review ). 15-20 (2016). doi:10.3892/etm.2015.2853

5. Yuan, Y.-Q. \& Al, E. Gender Difference on the Association between Middle-Aged and Elderly Populations. (2016). doi:10.3390/nu8080448

6. Pusat Data dan Informasi Kemenkes RI. Situasi dan Analisis Diabetes. Kementerian Kesehatan RI (2014).

7. Patel, P. \& Abate, N. Body Fat Distribution and Insulin Resistance. 2019-2027 (2013). doi:10.3390/nu5062019

8. Gommers, L. M. M., Hoenderop, J. G. J., Bindels, R. J. M. \& De Baaij, J. H. F. Hypomagnesemia in Type 2 Diabetes: A Vicious Crcle? Diabetes 65, 313 (2016).

9. Blair, S. N., Drenowatz, C., Shook, R. P., Hand, G. A. \& He, J. R. Diet Quality and Body Composition. 1-6 (2014). doi:10.1038/srep04928

10. Nurwanti, E., Uddin, M., Chang, J., Id, H. H. \& Syed-abdul, S. Roles of Sedentary Behaviors and Unhealthy Foods in Increasing the Obesity Risk in Adult Men and. (2018). doi:10.3390/nu10060704

11. Mazidi, M., Kengne, A. P., Mikhailidis, D. P., Toth, P. P. \& Ray, K. K. Dietary Food Patterns and Glucose / Insulin Homeostasis : A Cross-Sectional Study Involving 24, 182 Adult Americans. 1-9 (2017). doi:10.1186/s12944-017-0571-x

12. Lee, Y. J., Song, S. \& Song, Y. High-Carbohydrate Diets and Food Patterns and Their Associations with Metabolic Disease in the Korean Population. Yonsei Medical Journal. 59 (7), 834842 (2018).

13. Choe, S. S., Huh, J. Y., Hwang, I. J., Kim, J. I. \& Kim, J. B. Adipose Tissue Remodeling : its Role in energy Metabolism and Metabolic Disorders. 7, 1-16 (2016).

14. Zaakouk, A. M., Hassan, M. A. \& Tolba, O. A. Serum Magnesium Status among Obese Children and Adolescents. Egypt. Pediatr. Assoc. Gaz. 64, 32-37 (2015).

15. Chaudhary, R., Kumar, A. \& Sinha, R. B. Assessment of Serum Magnesium in Overweight Children at A Tertiary Care Hospital of Bihar. 159-161 (2018).

16. Suliburska, J. et al. The evaluation of Selected Serum Mineral Concentrations and Their Association with Insulin Resistance in Obese Adolescents. Eur. Rev. Med. Pharmacol. Sci. 17, 2396-2400 (2013).

17. Guerrero-Romero, F., Bermudez-Peña, C. \& Rodríguez-Morán, M. Severe Hypomagnesemia and Low-Grade Inflammation in Metabolic Syndrome. Magnes. Res. 24, 45-53 (2011).

18. Bertinato, J. et al. Lower Serum Magnesium
Concentration is Associated with Diabetes, Insulin Resistance, and Obesity in South Asian and White Canadian Women but Not Men. Food Nutr. Res. 59, 1-9 (2015)

19. O'Connell, B. S. Select Vitamins and Minerals in the Management of Diabetes. Diabetes Spectr. 14, 133-148 (2007).

20. Witkowski, M., Hubert, J. \& Mazur, A. Methods of Assessment of Magnesium Status in Humans : a systematic review. 24, 163-180 (2011).

21. Workinger, J. L., Doyle, R. P. \& Bortz, J. Challenges in The Diagnosis of Magnesium Status. Nutrients 10, 1-23 (2018).

22. Huerta, M. G. et al. Magnesium Deficiency is Associated with Insulin Resistance in Obese Children. Diabetes Care 28, 1175-1181 (2005).

23. Susiwati. Differences of Blood Glucose Blood Differences Patients Diabetes Mellitus Type 2 in Plasma NaF Based On Time in Examination In DR. M. Yunus Bengkulu In Year 2017. 6, 82-87 (2018).

24. Baharudin, Nurulita A, Arif M. Blood Glucose Test Between Hexokinase With Glucose Oxidase and Glucose Dehydrogenase Methods in Diabetes mellitus. Indones. J. Clin. Pathol. Med. Lab. 21, 170-173 (2015).

25. Kalita, N. \& Choudhury, B. D. A Cross Sectional Study Evaluating The Association of Serum Calcium, Serum Magnesium, and Body Mass Index in Premenopausal and Postmenopausal Women. Int. J. Res. Med. Sci. 5, 1953 (2017).

26. Milbouw, S. et al. Predictors of Insulin Resistance in Obesity and Type 2 Diabetes Mellitus - The Role of Magnesium. J. Metab. Syndr. 06, (2018).

27. Cosyns, E. et al. Gitelman Syndrome: Consensus and Guidance from a Kidney Disease: Improving Global Outcomes (KDIGO) Controversies Conference. 24-33 (2017). doi:10.1016/j.kint.2016.09.046

28. PERKENI. Pengelolaan dan Pencegahan Diabetes Melitus Tipe 2 di Indonesia 2015. (PB PERKENI 2015).

20. Nurrahmawati, F \& Fatmaningrum, W. Hubungan Usia, Stres, dan Asupan Zat Gizi Makro dengan Kejadian Obesitas Abdominal pada Ibu Rumah Tangga di Kelurahan Sidotopo, Surabaya. Amerta Nutr. 254-264 (2018).

30. Rahmandita, Ajeng Putri, Adriani, M. Perbedaan Tingkat Konsumsi dan Aktivitas Fisik pada Wanita ( 20-54 Tahun ) Obesitas Sentral dan Non Sentral. 266-274 (2017). doi:10.20473/amnt.v1.i4.2017.266-274

31. NK. Gungor. Overweight and Obesity in Children and Adolescents. J. Clin. Res. Pediatr. Endocrinol. 6, 129-143 (2014).

32. Coudray, C. et al. Human Nutrition and Metabolism Two Polyol, Low Digestible Carbohydrates Improve the Apparent Absorption of Magnesium. 90-93 (2003). 
33. Wei, J. et al. Association among dietary magnesium, serum magnesium, and diabetes: a cross- sectional study in middle-aged and older adults. J. Heal. Popul. Nutr. 1-6 (2016). doi:10.1186/s41043-016-0071-z

34. Jahnen-Dechent, W. \& Ketteler, M. Magnesium basics. CKJ Clin. Kidney J. 5, (2012).

35. Ermona, N. D. N. \& Wirjatmadi, B. Hubungan Aktivitas Fisik Dan Asupan Gizi Dengan Status Gizi Lebih Pada Anak Usia Sekolah Dasar Di Sdn Ketabang 1 Kota Surabaya Tahun 2017. 97-105 (2018). doi:10.20473/amnt.v2.i1.2018.97-105

36. Ahn, J., Kim, N., Lee, B. \& Park, S. Carbohydrate Intake Exhibited a Positive Association with the Risk of Metabolic Syndrome in Both SemiQuantitative Food Frequency Questionnaires and 24-Hour Recall in Women. (2017).

37. Sirajuddin, Surmita, A. T. Survei Konsumsi Pangan. (Kementerian Kesehatan RI, 2018).

38. Nabila R, Widyastuti N, Murbawani EA. Hubungan Lingkar Pergelangan Tangan Dengan Kadar Glukosa Darah Wanita Obesitas Usia 40 55 Tahun. J. Nutr. Collage 7, 92-99 (2018).

39. Dashty, M. A Quick Look at Biochemistry :Carbohydrate Metabolism. 13391352 (2013). doi:10.1016/j.clinbiochem.2013.04.027

40. Hardy, Olga T. \& Michael P. Czecha, and S. C. What Causes The Insulin Resistance Underlying Obesity? Curr Opin Endocrinol Diabetes Obes 19, 81-87 (2012).

41. GA.Balsan, JL.Da Costa Vieira, A. D. O. Relationship between Adiponectin, Obesity and Insulin Resistance. 61, 72-80 (2015).

42. Breneman, C. B. \& Tucker, L. Dietary Fibre Consumption and Insulin Resistance - The Role of Body Fat and Physical Activity. 375-383 (2018). doi:10.1017/S0007114512004953
43. Werdani, A. Carbohydrate Intake is a Dominant Factor Related to Fasting Blood Glucose Level. J. Kesehat. Masy. Nas. 9, (2014).

44. Gardner, C. D. et al. Effect of Low-Fat vs LowCarbohydrate Diet on 12-Month Weight Loss in Overweight Adults and the Association With Genotype Pattern or Insulin Secretion The DIETFITS Randomized Clinical Trial. 94305, 667679 (2018).

45. Mann, J. et al. FAO / WHO Scientific Update on Carbohydrates in Human Nutrition : conclusions. 61, 132-137 (2007).

46. Anderson, J. W. et al. Health Benefits of Dietary Fiber. (2009). doi:10.1111/j.17534887.2009.00189.x

47. Rotter, I. et al. Relationship between Serum Magnesium Concentration and Metabolic and Hormonal Disorders in Middle-Aged and Older Men. Magnes. Res. 28, 99-107 (2015).

48. Hassan, S. A. ul et al. Comparison of Serum Magnesium Levels in Overweight and Obese Children and Normal Weight Children. Cureus 9, (2017).

49. Ye \& Jianping. Mechanisms of Insulin Resistance in Obesity. Front Med 7, 14-24 (2013).

50. Lee, B.-C. \& \& Lee, J. Cellular and Molecular Players in Adipose Tissue Inflammation in the Development of Obesity-induced Insulin Resistance. 1842, 446-462 (2014).

51. Wuttke, A. Mini Review Lipid Signalling Dynamics at The b-cell Plasma Membrane. 281-290 (2015). doi:10.1111/bcpt.12369

52. Satoh, T. Molecular Mechanisms for The Regulation of Insulin-Stimulated Glucose Uptake by Small Guanosine Triphosphatases in Skeletal Muscle and Adipocytes. 18677-18692 (2014). doi:10.3390/ijms151018677 